\title{
Specific Forms of Residential Space in Urban Areas: Adaptation of the Public Space of Residential Structures in Post-socialist Countries
}

\section{Špecifické formy obytného priestoru v mestskom prostredí: Adaptácia verejného priestoru sídelných štruktúr v postsocialistických krajinách}

Daniela Majzlanová

Faculty of Architecture, Slovak University of Technology in Bratislava majzlan.daniela@gmail.com

\begin{abstract}
Dealing with the legacy of socialist mass housing planning is also a part of research on the public spaces of residential buildings. The same issues concern residential housing of the socialist period in Slovakia. The questions of the lifespan, transformation and intensification of the mass housing are common topics for different post-socialist countries. However, dealing with the legacy of socialism and humanization of settlements are different processes. In countries to the east of Slovakia, paradoxically, the context of less developed economy and of the local cultural and social characteristics has led to several innovative housing solutions. In our context, similar planning projects remained only on paper, while in Georgia, Armenia and the Ukraine, they have materialized. The paper focuses on a comparison of the development of housing and of public space based on the social and historical contexts of these countries, which have several common urban characteristics.
\end{abstract}

KEYWORDS: residential housing; adaptation; post-socialist housing; public space

ABSTRAKT: Súčastou výskumu verejných priestorov obytného prostredia je aj téma vyrovnávania sa s dedičstvom socialistickej masovej bytovej výstavby. Obytné súbory socialistického plánovania na Slovensku sa dnes stretávajú s podobnými probléma- 
mi. Otázky životnosti, trvalej udržatel’nosti, transformácie a intenzifikácie sídelných štruktúr sú však spoločnou témou viacerých krajín. Proces vysporiadania sa s dedičstvom socializmu a humanizácie sídlisk je rôzny. Kontext menej vyspelej ekonomiky a kultúrno-spoločenských špecifík krajín na východ od Slovenska paradoxne umožnil vzniknút variante viacerých inovatívnych riešení. V našom kontexte zostali podobné projekty iba na papieri, no v krajinách ako Gruzínsko, Arménsko a Ukrajina sa realizovali. Na porovnanie vývoja bývania a verejných priestorov v tomto príspevku slúži spoločenský a historický kontext týchto krajín, ktoré majú niekol'ko spoločných urbánnych charakteristík.

KLÍČOVÁ SLOVA: obytné budovy; adaptácia; postsocialistické sídlisko; verejný priestor

\section{Úvod}

Súčastou výskumu verejných priestorov obytného prostredia je aj téma vyrovnávania sa $s$ dedičstvom socialistickej masovej bytovej výstavby. Obytné súbory socialistického plánovania na Slovensku sa dnes stretávajú s podobnými problémami. Životnost' panelových sústav sa podla pôvodných odhadov blíži ku koncu a vynárajú sa otázky trvalej udržatel’nosti, transformácie a intenzifikácie sídelných štruktúr. Zažívame prerod nielen sídlisk, ale aj postojov obyvatelstva k nim. Dnes sú neoddelitelnou súčastou identity postsocialistických krajín. Proces vysporiadania sa s dedičstvom socializmu je však v jednotlivých krajinách a kultúrnych oblastiach rôzny. Kontext menej vyspelej ekonomiky a miestnych kultúrno-spoločenských špecifík krajín na východ od Slovenska paradoxne umožnil vzniknút variante viacerých inovatívnych riešení. Riešenie bytovej otázky a humanizácie sídlisk bolo spoločnou témou viacerých krajín aj československých projektových ústavov. Projekty rozširovania a humanizácie sídlisk zostali v našom kontexte iba na papieri, no v krajinách ako Gruzínsko, Arménsko a Ukrajina sa realizovali. Na porovnanie vývoja bývania a verejných priestorov $\mathrm{v}$ tomto príspevku slúži spoločenský a historický kontext týchto troch krajín. Mestá majú niekol'ko spoločných charakteristík, ktoré definujú urbánne priestory postsocialistických republík. Môžeme identifikovat niekolko stratégií prisvojovania si verejného priestoru obyvatelmi. Na ich stav vplýva nepochybne viacero faktorov, ekonomická situácia, kultúrne zvyklosti i miera regulácie.

\section{Typologické prvky obytného a verejného priestoru}

Najvýraznejšie vnímatel’né stavebné prvky sídlisk sú tzv. kamikadze lodžie (1) v Gruzínsku, samostatná vertikálna vrstva prístavieb obytných budov. Toto rozširovanie 
obytného priestoru na fasádach výškových budov nielen panelovej sídliskovej výstavby je charakteristickým znakom gruzínskych sídlisk. Zámer štátneho projektového ústavu z roku 1985 o zvýšenie kvality bývania a vyriešenie nedostatočnej bytovej plochy formou pristavanej konštrukcie, dostavanej na vlastné náklady majitelov, vyústil do podoby fasádnych prístavieb najrozmanitejších foriem a materiálov. Nedostatok financií, nedôsledná alebo žiadna regulácia, no aj invencia miestnych obyvatelov prispela nielen $\mathrm{k}$ vizuálnej, ale aj funkčnej diverzite architektúry. Individualita úprav priestorov je často kompromisom ekonomických možností a individuálneho vkusu rezidentov. Ich kvalita je neraz diskutabilná, množstvo úprav sa zd’aleka neriadi normami alebo všeobecnými regulatívmi, vytvára však pozoruhodne pestrú samoorganizovanú urbánnu vrstvu.

„V relatívne indiferentnom fyzickom prostredí vzniká slabý emocionálny výboj, nedostačujúci na indukciu pozitívneho vztahu k prostrediu. Je teda pozitívne pôsobenie úmerné stupñu jeho rozmanitosti a špecifickosti v závislosti od kultúrno-spoločenskej tradície a geografickým podmienok daného miesta." (2)

Výrok architekta Imricha Jankovicha potvrdzuje, že aj v našich podmienkach výstavby sa architekti stretávali s negatívnym postojom obyvatelov $\mathrm{k}$ jednotvárnemu obytnému prostrediu a hladali nové spôsoby prirodzenej a umelej typizácie, ktoré by vyriešili problém zanedbávania kultúrnych špecifík, teda „genia loci“, aj kvalitatívnych a kvantitatívnych nárokov na bývanie. Pozoruhodné je, že v osemdesiatych rokoch sa aj u nás pokúsili architekti v spolupráci s Pražským projektovým ústavom obdobne riešit sterilnost’ a uniformitu sídlisk. Typizovanými prídavnými konštrukčnými nosnými aj nenosnými prvkami a sústavami sa dopracovali k princípu volnej fasády s možnostou vrstvenia podlaží do poschodí nad sebou. To, čo však v našich podmienkach zostalo iba víziou na papieri, sa v Gruzínsku podarilo zrealizovat vtedajším projektovým ústavom. Pod tlakom plnenia plánov bytovej výstavby však bol zámer nekoncepčne odovzdaný do réžie samotných obyvatelov.

Analýza typologických prvkov obytného a verejného priestoru Arménska, Ukrajiny, no najmä Gruzínska priniesla niekol'ko osobitostí, ktoré sú v kontraste so situáciou verejných priestranstiev na Slovensku. Sú dôležitou súčastou „medzipriestoru“, rozhrania medzi verejným a súkromným priestorom, ktoré tvorí aktívny spoločenský priestor sčasti skrytý, sčasti odohrávajúci sa verejne. Pozorujeme niekolko fenoménov, ktoré sa odrážajú v typológii architektúry. Prvky verejného priestoru ako podchody, podlubia, exteriérové stolovania, altánky, pitné fontánky, trhoviská sú aktívnymi spoločenskými bodmi. Prvky, ktoré sú integrálnou súčastou obytného priestoru ako lodžie, balkóny, verandy, pavlače, podbránia, exteriérové schody, vnútrobloky, sú intenzívne využívané rezidentmi alebo blízkou komunitou. Sú miestami náhodných aj plánovaných stretnutí. Spoločným znakom obytných štruktúr sú silné 
individuálne stavebné zásahy, prispôsobovanie si najbližšieho okolia domu za účelom rozširovania obytnej plochy nadstavbami a prístavbami na fasáde bytových domov.

\section{Privatizácia verejného priestoru}

Po rozpade Sovietskeho zväzu v roku 1992 prešla drvivá väčšina bytového fondu v Gruzínsku do súkromného vlastníctva. Nestabilná ekonomická a spoločenská situácia mala za následok aj neregulované privlastňovanie si verejného priestoru a jeho zastavanie garážami, malými záhradami, obchodmi, parkoviskami, atd. (3) Nelahká životná situácia obyvatelov však paradoxne vyprodukovala množstvo inovatívnych riešení typológie bytových priestorov vytváraním občianskej vybavenosti a služieb, čím diverzifikovala monofunkčné obytné štvrte, celé mestské ulice aj verejné priestranstvá, a neoddelitel’ne sa podpísala pod architektonický kolorit miest. Avšak absencia kontroly výstavby a chýbajúce územné plánovanie malo za následok aj neriadenú výstavbu v mnohých parkoch, uliciach a námestiach, s čím mestá zápasia dodnes. Zatial’ čo v našom regióne sa sídliská ako forma sociálneho bývania dočkali renesancie a v mnohých prípadoch obnovy a niekedy aj následnej gentrifikácie, vo východnejších postsocialistických krajinách sú neobnovené sídliská nad’alej bežným štandardom bývania. Vnútri sú však byty často komfortne zariadené, čo je v protiklade s ich schátraným vonkajškom.

Podchody sú významným prvkom urbánnej infraštruktúry vyskytujúcej sa v obytných zónach alebo na ich okrajoch. V Gruzínsku, na Ukrajine i v Arménsku nepredstavujú iba tranzitnú zónu, velké podchody v mestách sú aktívnou súčastou spoločenského diania, je to plne funkčné „mesto v meste“. Vybavené najrozmanitejšími obchodnými a stravovacími prevádzkami a službami je ekvivalentom nákupných centier. Občianska vybavenost’ zabezpečuje kontrolu a udržiavanie priestorov aj do neskorých hodín. Či sa jedná o nezrekonštruované podchody preplnené lacným tovarom, alebo o luxusné prevádzky napojené na novostavby nákupných centier alebo nových obytných komplexov, vždy sú to strategicky umiestnené pasáže, cez ktoré prirodzene prúdi množstvo ludí. Mnohokrát majú obrovské rozmery a niekolko východov na viacero ulíc. Obdobne je to s trhoviskami, ktoré bývajú súčastou takmer každého, aj najmenšieho mesta. Na vytvorenie malého trhu častokrát stačí niekol'ko stánkov rozložených na okraji ulice, najmä pozdľž hlavnej komunikácie vo štvrtiach rodinných domov, kde obyvatelia priamo spred domov a dvorov predávajú svoju domácu produkciu. $\mathrm{V}$ tradičnom duchu je trhovisko nielen dôležitým miestom podpory lokálnej ekonomiky, ale je aj epicentrom verejného diania. Aj dnes je prirodzenou a neoddelitelnou častou každodenného života obyvatelov. Je to priestor pre stretávania sa, neustálu výmenu tovaru, ludí a informácií, ktorá má spolu s diverzitou ponúkaných tovarov intenzívny, neopakovatelný zmyslový rozmer pre každého návštevníka. Práve toto verejné miesto je priestorom pre vyrozprávanie príbehov každého 
mesta. (4)

Formou menším, no o to častejšie vyskytujúcim sa prvkom naznačujúcim privátne využívanie verejného obytného priestoru je exteriérové sedenie. Strategicky umiestnené na priedomiach domov, obchodov, pred bránami domov, pri pitných studničkách, zastávkach, popri cestách a stromoch umožňuje oddych a najmä sociálny kontakt miestnych aj nerezidentov. Má najrôznejšie podoby, od najjednoduchších materiálových a konštrukčných riešení, až po kompletné stolovanie v altánkoch rodinných záhrad, vnútroblokov alebo parkov. Zdá sa, že práve tu sa v tej najprostejšej forme ukazuje, že „predovšetkým však vizuálna stránka verejných priestorov sama neprezrádza, ako sa naplňuje ich sociálny zmysel."(5) Tieto prvky sú strategicky umiestnené, čím sa stávajú významnými atraktormi spoločenského života a nenásilne prepájajú súkromné priestory s verejnými.

Mierou úspešnosti dobrého architektonického návrhu je jeho používanie samotnými lud’mi. Ak je prvok strategicky umiestnený, niekedy je aj obyčajný kus dreva rovnako dobre, ba dokonca úspešnejšie fungujúcou súčastou verejného priestoru než premyslený ergonomický dizajn lavičky. Je prirodzene akceptovaný a stane sa plnohodnotnou súčastou života obyvatelov. Spoločenské zvyklosti obyvatelov sa odohrávajú na rôznych úrovniach, v súkromnom a verejnom priestore, no kontakt s mestom a teda vytváraním mestskosti sa odohráva na rozhraní medzi interiérom a exteriérom, v poloverejných priestoroch.

\section{Záver}

Aj ked' dôsledky masovej socialistickej výstavby sú spoločným dedičstvom bývalých totalitných krajín, neskorší vývoj ukázal odlišné smerovanie. Avšak jedinečnost’ architektúry spočíva aj v špecifických odtieňoch daného regiónu. Prejavuje sa aj v individuálnej snahe obyvatel’ov potlačit monotónnost̉ rezidenčných výškových budov, ktoré si adaptujú na miestne podmienky a zvyklosti. Na uvedených príkladoch vidíme, že občianska vybavenost’ a individuálny vklad obyvatelov je nevyhnutným predpokladom na úspešné osvojenie si verejného priestoru obyvatelmi a na vytváranie pevných vztahov s prostredím. 


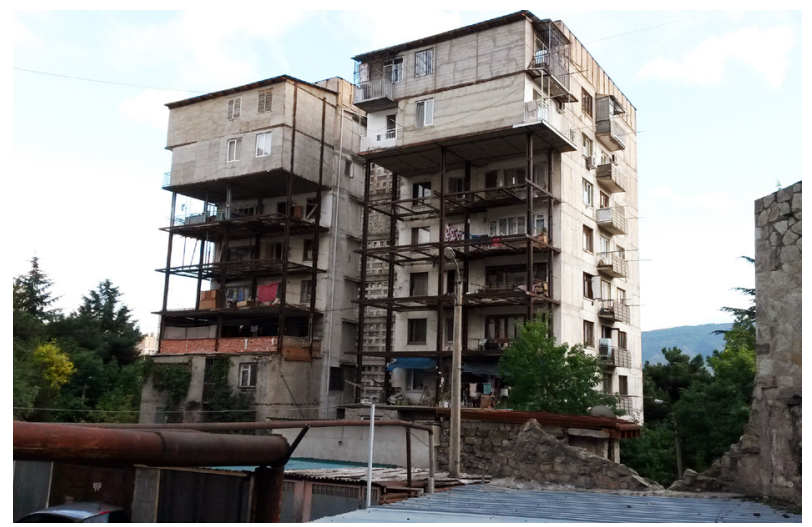

Obr. 1. Kamikadze lodžie, Nutsubidze plato, Tbilisi (Zdroj: foto Daniela Majzlanová, 2015)

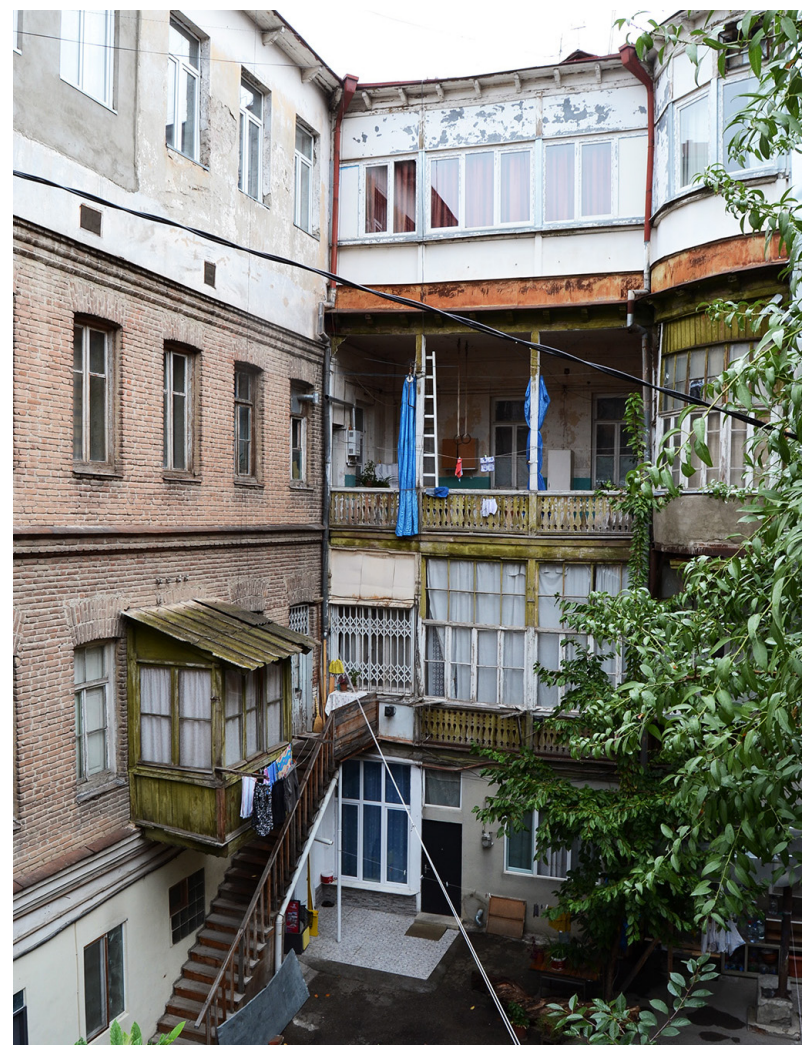

Obr. 2. Vnútrobolok v centre Tbilisi, Gruzínsko (Zdroj: foto Daniela Majzlanová, 2015) 


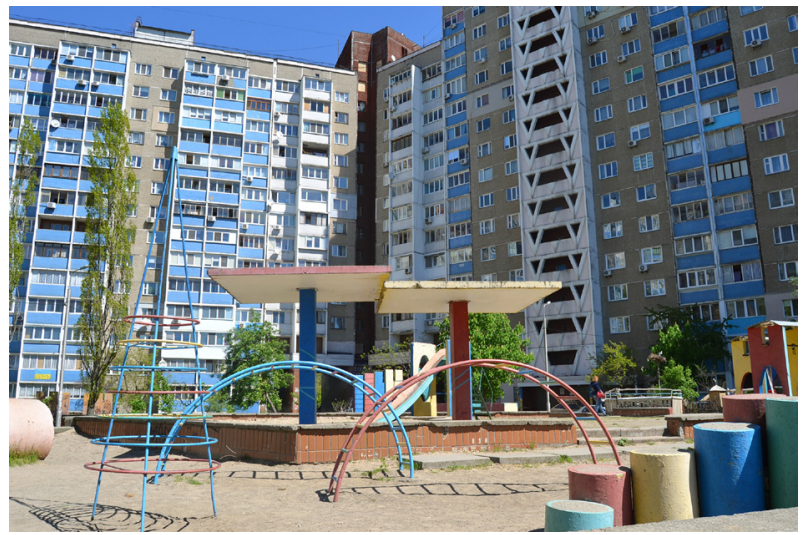

Obr. 3. Vnútroblok sídliska Teremki, Kyjev, Ukrajina (Zdroj: foto Daniela Majzlanová, 2016)

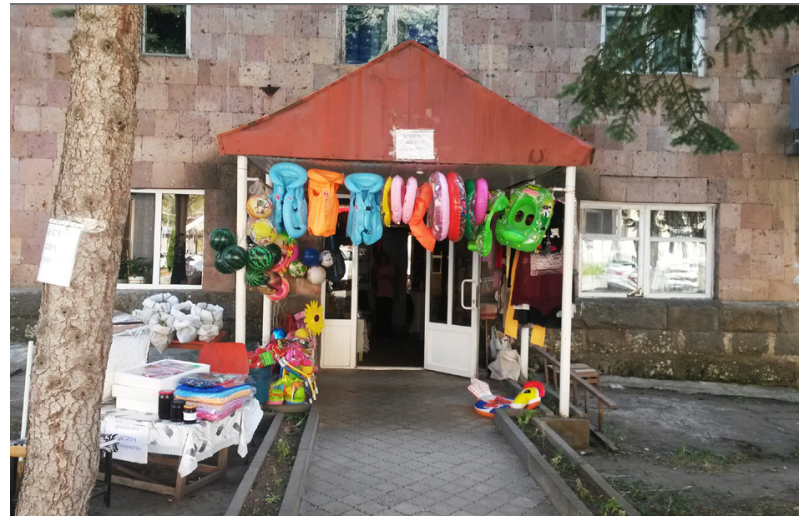

Obr. 4. Parter obytného domu, Jermuk, Arménsko (Zdroj: foto Daniela Majzlanová, 2016)

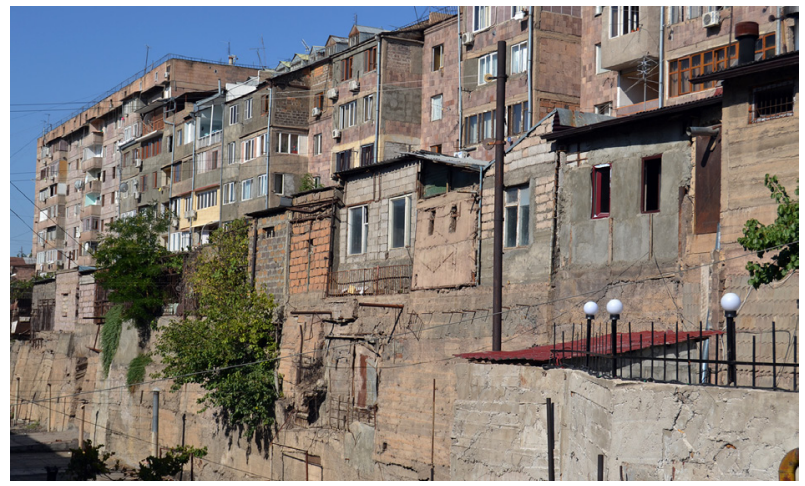

Obr. 5. Vnútroblok sídliska v Jerevane, Arménsko (Zdroj: foto Daniela Majzlanová, 2016) 


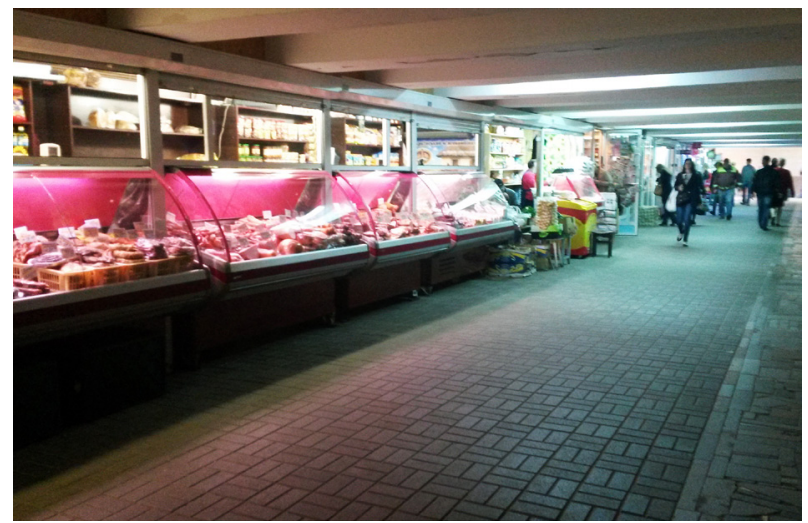

Obr. 6. Podchod v Kyjeve, Ukrajina (Zdroj: foto Daniela Majzlanová, 2016)

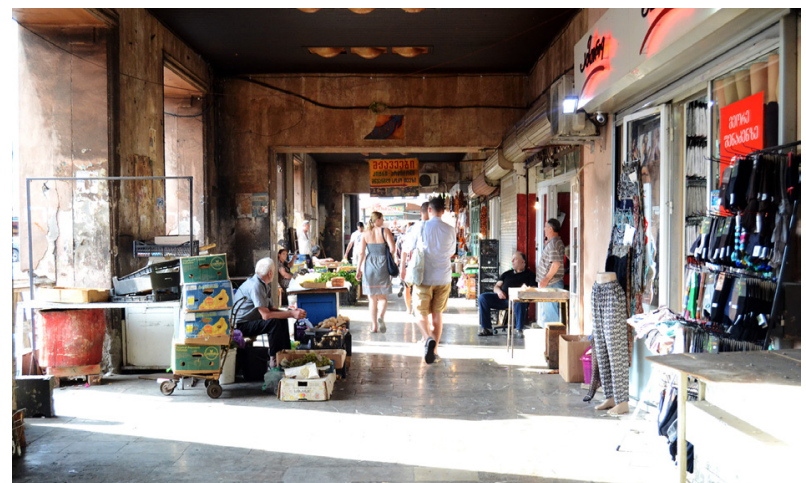

Obr. 7. Podlubie v Tbilisi, Gruzínsko (Zdroj: foto Daniela Majzlanová, 2016)

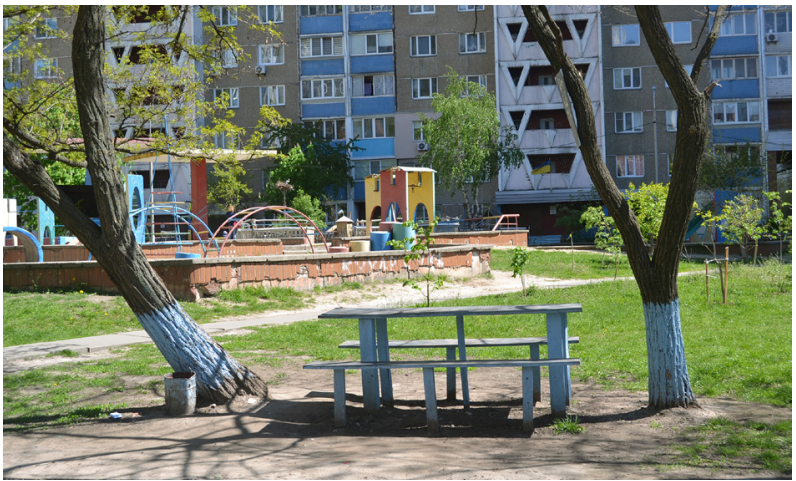

Obr. 8. Exteriérové stolovanie na sídlisku Teremki, Ukrajina (Zdroj: foto Daniela Majzlanová, 2016) 


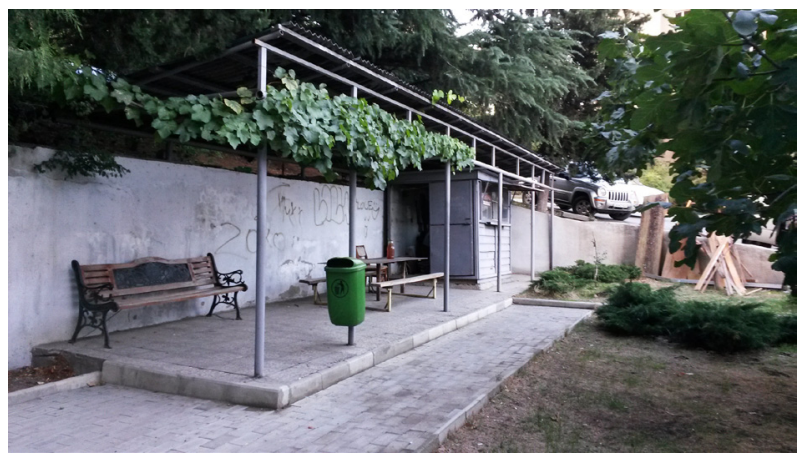

Obr. 9. Exteriérové stolovanie s vinárňou na sídlisku v Tbilisi, Gruzínsko (Zdroj: foto Daniela Majzlanová, 2015)

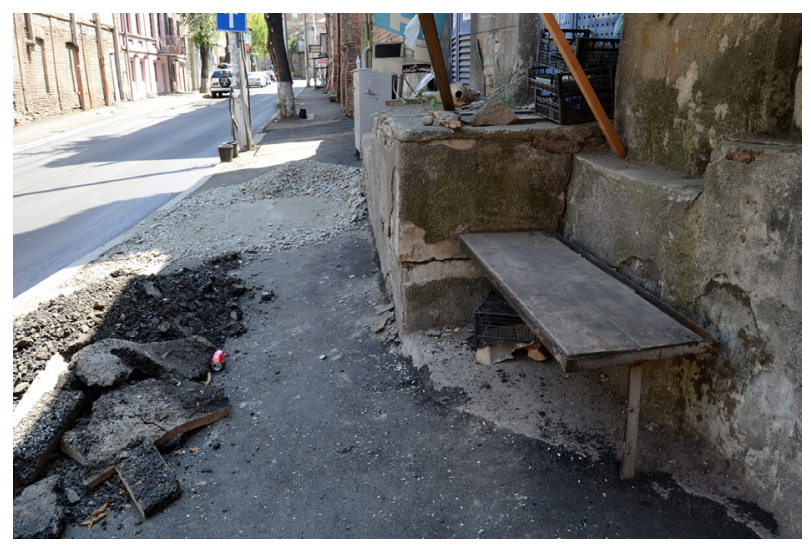

Obr. 10. Lavička na priedomí v Tbilisi, Gruzínsko (Zdroj: foto Daniela Majzlanová, 2016)

\section{Prameny}

1. Zaiček, Martin. Architektúra Tbilisi vo vibráciách posledných dekád. In Alfa, 4/2015, s. 58-59. ISSN 1335-2679.

2. Jankovich, Imrich. Spoločenské požiadavky na vývoj nových stavebných sústav pre komplexnú byvtovú výstavbu. Projekt, 7/239/80. s. 4

3. Asabashvili, Levan - Mirzikashvili, Rusudan. Post war housing in Georgia. Fitch colloquium: Why Preserve Public Housing, conducted at the Columbia University. http://urbanreactor.blogspot.sk/2012/04/post-war-housing-in-georgia.html

4. Kratochvíl, Petr . Městský veřejný prostor. Praha, Zlatý řez, 2015, s. 22.

5. Kratochvíl, Petr. Městský veřejný prostor. Praha, Zlatý řez, 2015, s. 28. 